\title{
THE
}

$1-1-2017$

\section{Mapping Fashion in the 'City by the Sea': Shopping Districts in Newport, Rhode Island}

\author{
Linda Welters \\ University of Rhode Island, Iwelters@uri.edu \\ Jennifer Pisula \\ Megan Martinelli \\ Mary Elizabeth Corrigan \\ Sarah Lockrem
}

See next page for additional authors Follow this and additınal works at: https://digitalcommons.uri.edu/tmd_facpubs

The University of Rhode Island Faculty have made this article openly available. Please let us know how Open Access to this research benefits you.

This is a pre-publication author manuscript of the final, published article.

Terms of Use

This article is made available under the terms and conditions applicable towards Open Access Policy Articles, as set forth in our Terms of Use.

\section{Citation/Publisher Attribution}

Welters, Linda et al. "Mapping fashion in the 'City by the Sea': Shopping districts in Newport, Rhode Island." Fashion, Style and Popular Culture, vol. 4 no. 1. January 1, 2017. https://doi.org/10.1386/

fspc.4.1.7_1

This Article is brought to you for free and open access by the Textiles, Fashion Merchandising and Design at DigitalCommons@URI. It has been accepted for inclusion in Textiles, Fashion Merchandising and Design Faculty Publications by an authorized administrator of DigitalCommons@URI. For more information, please contact digitalcommons-group@uri.edu. 


\section{Authors}

Linda Welters, Jennifer Pisula, Megan Martinelli, Mary Elizabeth Corrigan, Sarah Lockrem, Sarah Templeton, Sarah Yang, Holly Paquette, Catherine Murphy, and Hilary Baker 


\section{Mapping Fashion in the 'City by the Sea': Shopping Districts in Newport, Rhode Island}

Newport, Rhode Island is internationally recognized for both its prime location on Narragansett Bay and its storied history. Nicknamed the 'City by the Sea,' it is famous for world-class sailing, colonial New England architecture, Gilded Age mansions, trendy restaurants and bars, and nearby beaches.

Since the late 1970s cultural tourism (or heritage tourism) has been a multi-billion dollar business for Rhode Island, and shopping has become an integral part of that business. Whether for a day-long trip, a weekend getaway or month-long vacation, people shop when visiting tourist locations. According to sociologist Sharon Zukin, shopping is such an important component of the American economy that it could be considered part of the national culture (Zukin 2004). Evidence of its importance can be found in Newport where shopping is the fourth largest generator of revenue (after accommodation, food and entertainment), bringing in nearly one billion dollars in sales in 2013. Fashionable clothing and accessories make up a significant portion of these sales (IHS Consulting 2013).

Retail shopping venues in cities have a close reciprocal relationship to their cultural landscape - people, physical environment, cultural heritage, and geography. Thus, the fashion landscape easily contributes to the image of a town and vice versa. The same could be said of a resort city such as Newport. Although scholars have studied the fashion-city relationship of Paris, Milan, New York and other major 'fashion cities,' this 
relationship in smaller communities has not appeared in the literature. To fill the gap, this article explores the fashion retail sector in the resort city of Newport and the ways in which accessible shopping impacts the image of the city.

\section{FASHION, CITIES, AND SHOPPING}

Much has been written about the relationship between the production and consumption of fashion in the world's major cities, and the associated symbolism of those cities as fashion capitals. In Fashion's World Cities, Christopher Breward noted that stakeholders 'have come to see fashion as an important contributor to the broader promotion of the cultural and creative economy of major global cities' (Breward 2006: ix). The accepted list of first-tier global fashion cities includes Paris, New York, London, Milan, and Tokyo. David Gilbert (2006) described fashion cities as having a cluster of creative designers, affordable rental spaces for designers, fashion production networks, cultural institutions that display fashion, recognized promotional vehicles, and fashion research and training institutes. Gilbert also discussed the significance of cities as sites of consumption including distinctive built environments, symbolically significant streets and districts for shopping, unique independent shops, and a fashion tradition with placespecific elements.

In the second decade of the twenty-first century, many cities across the globe are vying to be recognized for fashion. Melbourne, Australia has sought to overcome its reputation as Australia's second fashion city (after Sydney) through L'Oreal Fashion Week (Weller 2011). In the United States, the city of Chicago, through an initiative developed by the mayor's office, launched a full-scale effort to gain a share of the 
American fashion pie including naming its own fashion director (Gamble 2011).

Antwerp, Belgium became a successful fashion capital without following the accepted formula of hosting a fashion week by consciously linking its avant-garde fashion status to an external public who see Antwerp as a travel destination (Martínez 2007). Even the city of Belgrade in Serbia has been studied as an alternative site for fashion tourism (Demirovic and Pivac 2013).

Shops and the shopping experience are integral to a city's fashion reputation. Olga Vainshtein (2006) mapped Moscow's fashion landscape, discussing distinctive shopping districts in light of competing economic models. In Belgium, promoters developed a guided fashion walk that stopped at the flagship stores of Antwerp's leading avant-garde designers. Fashionable shops got on the tourist route because they had been intellectualized and historicized, not just because they were shops (Martínez 2007). Norma Rantisi examined second-tier fashion centers striving for distinct identities as places to market fashion products. She stated that 'fashion contributes to place-branding and the promotion of tourism; it also contributes to defining the aesthetics of a place which in turn, can shape the design and marketing of cultural products' (2011:260). Rantisi focused on boutiques, noting that they incorporate place-specific elements and evolving design traditions. Boutiques add diversity and character to a retail landscape crowded with big-box stores and national chains through distinctive architecture, interior design, and product offerings as well as close buyer-customer relations.

Susan Kaiser noted that while attention has been focused on world cities of fashion, ways to support fashion communities in small and medium cities are needed to 
allow these places to enjoy the benefits that fashion districts can bring to their cities (Kaiser and Michalski 2012: 145).

The authors of this study asked, 'Where does Newport fit on this trajectory?' Newport has distinctive architecture, a multi-faceted cultural heritage, and a unique geographical location. But what is the city's fashion identity, and how does it relate to shopping? To answer these questions, the authors examined Newport's history and its profile today, and they mapped the shopping districts. ${ }^{1}$ The mapping process included descriptions and analysis of Newport's fashion retail sector, followed by comparisons to the distinctive characteristics of major fashion cities worldwide.

To facilitate their research, the authors adapted the Newport Discovery Guide's breakdown of the city's shopping districts resulting in nine areas of approximately equal size: 1) Brick Market Place, 2) Upper Thames Street, 3) Bowen’s Wharf, Bannister's Wharf, and America's Cup Avenue, 4) Lower Thames Street, 5) Franklin Street and Spring Street, 6) Bellevue Avenue, 7) Washington Square and Long Wharf, 8) Broadway, and 9) Newport Mall (Newport Discovery Guide 2009-2012). Avenues, boulevards, piers, and other geographical boundaries separate the nine districts.

The researchers mapped the businesses in each of the districts by street addresses. Using an ethnographic approach (Flynn and Foster 2009: 174), they described the general tone of the street, zeroing in on fashion stores selling men's and women's clothing and accessories. Researchers noted if a store was part of a national or regional chain or unique to Newport. They viewed the merchandise in the stores and surveyed store websites to better assess store types, target markets, price points, and retail strategies. Researchers determined price points using Elaine Stone's six major retail price zones: designer, 
bridge, better, contemporary, moderate, and budget (2008). The researchers analyzed the shopping areas in light of Newport's history and culture and relevant materials published about the relationship between cities and fashion.

\section{NEWPORT'S HISTORY}

Newport is a small city on the southern tip of Aquidneck Island that faces Narragansett Bay to the west and Rhode Island Sound and the Atlantic Ocean to the south and east. Newport was founded in 1639 as a 'lively experiment' in religious freedom, and was soon populated by Quakers, Protestants, and Jews. The city was incorporated in 1784.

Because of its great natural harbor, Newport became one of America's leading colonial cities along with Boston, New York, Philadelphia, and Charleston. By the third quarter of the eighteenth century, Newport had over 150 wharves along the waterfront (Newport Historical Society 2015). (See Figure 1.)

The commercial activity allowed sea captains to make fortunes through trade. The owners of plantations (farms) on Aquidneck Island or across Narragansett Bay in South County likewise gained considerable wealth. Evidence of these past fortunes is still visible in the large, stately colonial homes situated throughout Aquidneck Island. The wealth meant that artisans could flourish, particularly silversmiths and furniture makers such as the renowned Townsend-Goddard family.

During the revolutionary war, when the British occupied Newport, all legitimate trade came to a halt (Stensrud 2006). When the British left, approximately fifty wealthy Tory families with allegiance to England departed as well. The town went into decay and lost its importance as a commercial center. Newport's demise allowed Providence, 
further up Narragansett Bay, to take over as Rhode Island's political and economic center (Jefferys 1976).

Newport, however, did not remain in desperate straits for long. Its fortunes rose during the Victorian era owing, in part, to its cool summer breezes and seaside location. The city attracted wealthy Americans, both old money and nouveau riche, who built 'summer cottages' to escape hot weather in their year-round communities. Families such as the Vanderbilts, Oelrichs, and Belmonts retained America's best-known architectural firm (McKim, Mead, and White) to design their summer residences. The mansions, with their well-manicured lawns and sweeping views of the Atlantic Ocean, were located far from the hustle and bustle of the downtown harbor area (Williams 2010). On the ocean side was Cliff Walk, a two-mile path above the coastline; on the street side was Bellevue Avenue. Beaches bracketed each end of Cliff Walk with private clubs catering to the wealthy at the end furthest from town (Jefferys 1976).

Shopping flourished to support the new wealthy clientele. In the late nineteenth century, Newport's retail growth paralleled developments in other cities. Its leading department store, Leys Century Store, was on Thames Street, in the heart of downtown (Baker 2011). Nearer the mansions, at the junction of Bellevue Avenue and Memorial Boulevard, an 1870-71 half-timber building by Richard Morris Hunt housed retail shops and the Newport Reading Room, a 'men's only' club for well-to-do summer residents. It was known as the Travers Block. Next door was the Newport Casino, a shingle-style building designed by McKim, Mead and White that included a rival reading room, restaurants, shops, and tennis courts. Bellevue Avenue was the center of the summer social scene and a lively commercial area for the summer colony. 
Lavish social events, balls, and sporting activities required extensive wardrobes in the Gilded Age. Summer residents likely arrived with trunks of clothes acquired in New York or Europe; others shopped in Newport. According to socialite Maud Howe Elliott, retailers from London, Paris, and New York set up temporary shops on Bellevue Avenue during the summer (1944: 155-6).

The introduction of the federal income tax and the Great Depression dampened Newport's position as the 'Queen of Resorts,' at which time the city capitalized on other assets, namely its waterfront location. In 1930 the New York Yacht Club, many of whose members were summer residents, moved the America's Cup trials and finals from New York Harbor to Newport. Thirteen America's Cup races were held in the waters off Newport until the Club lost the trophy to Australia in 1983 (Stensrud 2006). Other waterfront events that attracted visitors included Tall Ships from around the world, beginning in 1976 as part of the US Bicentennial celebrations.

The US Navy has had a presence in Newport since the Revolutionary War. Training of recruits began at the Naval War College in 1884. The Navy presence expanded in the twentieth century, peaking in the 1950s and 1960s with the building of piers to accommodate ships. The addition of tens of thousands of sailors brought muchneeded income to the local economy, but also a reputation as a rough town with seedy bars and dance halls. In 1973, the Navy moved the fleet to Norfolk, Virginia, leaving only officer training at the War College (Stensrud 2006).

The city raised its stature in September 1953, when hundreds of people gathered at St. Mary's Catholic Church for the marriage of Jacqueline Lee Bouvier to John F. 
Kennedy. After the ceremony, the guests celebrated at Hammersmith Farm, the summer home of Jackie's stepfather Hugh Dudley Auchincloss Jr. (Davis 2009: 186-8).

A drawback for Newport becoming a notable 'fashion city' has been its geographical location. Until the twentieth century the city was accessible only by ferry service. The most direct route for New Yorkers required taking two ferries until 1940, when a bridge from the mainland to the island of Jamestown reduced the number of ferry rides to one (Jefferys 1976). Newport's insular character permanently changed in 1969 with the completion of the Pell Bridge that connected Newport to Jamestown. This new route to the city set the stage for Newport's renaissance as a tourist destination.

The bridge completion coincided with renovations to the downtown area that came as part of the urban renewal sweeping America. Newport faced many challenges during the 1960s. Its harbor was industrial rather than recreational. It had a gas refinery, coal plants, a car dealership, and ferry docks directly on the waterfront. Even worse, the city's sewage seeped into the harbor through cracked and broken pipes. In addition, dilapidated buildings bordered Thames Street, the main shopping thoroughfare, where in 1962 fifteen stores stood vacant (Leys 2012). Bars along the harbor front served sailors rather than tourists. The Newport Redevelopment Agency, which had formed in 1949, sought to solve these problems by creating an attractive waterfront that catered to tourism, including spaces for shopping.

By 1973 the urban renewal project ended, and many changes were in place. A new street called America's Cup Avenue funneled traffic toward the waterfront instead of through congested Thames Street, Newport's 'main street.' The city had the harbor dredged, the sewage system upgraded, and a sea wall constructed where old industrial 
buildings had stood (Leys 2012). Moorings and docks for sail and powerboats soon appeared. Restored schooners and sloops began giving harbor tours. Redevelopment included moving colonial buildings to the waterfront area and renovating Bannister's Wharf and Bowen's Wharf which were expected to be the centerpiece of the plan. Brick walkways connected a mix of restaurants, bars, and shops in the wharf areas. The block in front of Trinity Church, a white clapboard structure with a prominent steeple built in 1726, was cleared for a green space called Queen Anne's Square.

Simultaneously, preservation groups began buying and renovating Newport's abundant stock of historic houses. Newport has more intact seventeenth- and eighteenthcentury buildings than any community in America (Jefferys 1976, Stensrud 2006). Grassroots organizations saved many historical buildings during the 1930s, 1940s, and 1950s. The Newport Historical Society, chartered in 1854, acquired seven historic properties. The Preservation Society of Newport County, formed in 1945, obtained eight Gilded Age mansions, one colonial house, and a topiary garden. The Newport Restoration Foundation, founded by tobacco heiress Doris Duke in 1968, preserved eighty-three historic structures, mostly homes that are rented to Newport residents.

By the later 1970s, after the Navy pulled out and the Tall Ships sailed into the harbor, Newport had transformed itself into a resort destination with a strong historical aesthetic that embraced the colonial era, the Gilded Age, and yachting. The era of heritage tourism had begun.

\section{NEWPORT TODAY}


Newport covers 11 square miles, which includes 7.7 square miles of land and 3.3 miles of inland water. It is a compact town with distinct residential and commercial districts. According to the FY 2013-2014 Budget, Newport's population was 24,672 and the average household income was $\$ 57,640$, which was slightly higher than the state's average (City of Newport 2013). Despite Newport's reputation as a playground for the wealthy, it has a significant low-income population. The Navy trains officers at the War College, and is the city's largest employer. Newport's Bellevue Avenue still has a summer season that draws wealthy residents from Boston, New York, and beyond. Vessels of all shapes and sizes fill the harbor during the summer, and cruise ships anchor in Narragansett Bay from May to early November.

Most visitors who are drawn to Newport's multiple historical and recreational attractions are affluent middle-class Americans (Williams 2010). Tourists who arrive by car exit the Pell Bridge to 'Scenic Newport' which allows them to bypass the poor sections of town. Instead, colonial burial grounds and historic buildings are immediately visible. Visitors coming by sea disembark at various points along the harbor front; most cruise ships deposit passengers near Long Wharf where chartered busses await to take them to the mansions.

Newport's architectural heritage ranges from colonial buildings to Gilded Age mansions. The Newport Historical Society, the Newport Preservation Society, and the Newport Restoration Foundation oversee more than 100 historic structures. Many other neighborhoods with historic houses are under the jurisdiction of the Historic District Commission, which reviews and approves exterior renovations to private or public 
buildings in the named districts. The result is a city whose residential and commercial buildings contribute greatly to its character.

Several educational facilities are situated in Newport, which adds a substantial student population. Salve Regina University occupies numerous former 'summer cottages' along Bellevue Avenue. A branch of the Community College of Rhode Island sits on the outskirts of town. The region also is home to several private schools for K-12.

Newport has a reputation from the Kennedy era as a place to hold weddings.

Some mansions and other large houses can be rented for wedding receptions. The city is also a site for bachelorette parties.

As with other resort communities near ocean beaches, Newport is packed in the summer. Its location on Narragansett Bay guarantees a warm fall, but a cool spring. During the winter months, when pedestrian traffic all but disappears, tourism is slow. Many fledgling businesses struggle at that time, and consequently fail after one or two seasons. To encourage year-round visitors, Newport hosts numerous events throughout the year. Table 1 lists many of these events, few of which, however, are fashion related. Yet, shopping is one of the activities promoted by Newport's various websites, and retail is the city's third largest private employer (City of Newport 2013).

\section{SHOPPING DISTRICTS}

This section explores Newport's shopping districts beginning with the Brick Market, which was the heart of Newport's commercial district during the colonial period. (See map in Figure 2.) 


\section{Brick Market Place}

Brick Market Place was developed as a commercial and residential complex in 1974-75. It is named after Newport's colonial-era Brick Market, an arcaded building completed in 1762, which houses the Museum of Newport History. Its staggered two and three-story buildings have retail shops and offices on the ground level and residential condominiums on the upper level. The buildings evoke quintessential New England through their architecture. Exteriors alternate between weathered shingles and narrow clapboards painted barn red, neoclassical white, or Cape Cod gray. Brick Market Place's three rows of buildings - Swinburne Row, Goddard Row, and Swan's Wharf Row - are separated by brick walkways. Swinburne gets the highest foot traffic because it abuts Thames Street, the city's historic shopping street.

Brick Market Place includes twenty-six stores offering fashion goods ranging from T-shirts to business suits. Although stores such as Brooks Brothers are part of national chains, most are independently owned. Many stores cater to tourists, offering sunglasses, Newport-themed sweatshirts, and resort-style clothing. Brick Market Place's

tag line is 'your kind of place' implying that there is something for everyone. It is close to where cruise ship passengers come ashore, and many stores offer small items that are easily packed.

This shopping district suffers high turnover, particularly Goddard Row and Swan's Wharf Row. Only one of the original tenants remains, a moderately priced footwear shop called Sole Desire Shoes that is popular with locals as well as tourists (Figure 3). Overall, Brick Market Place's retail shops project a mixed identity despite the attractive setting. 


\section{Upper Thames Street}

The Upper Thames Street shopping district begins cross from the Brick Market. This district is a commercial, tourist-driven area with restaurants, bars, art galleries, and retail shops. Within sight of the harbor, it consists of nineteenth-century storefronts situated on either side of Queen Anne Square. The street itself is paved with Belgian blocks, contributing to the area's historic atmosphere. Upper Thames Street is family oriented during the day, providing tourists and locals alike with places to shop, eat, and be entertained. At night it turns into a lively bar scene.

The retail mix includes a convenience store and a furniture store as well as fashion retailers. This street includes national chains Banana Republic, Chico's, Express, Rockport (shoes), Sunglass Hut, Jack Wills University Outfitters, and Helly Hansen. While price points are moderate to better, the fashion merchandise appeals to a wide range of target markets. Banana Republic caters to young professionals, while Chico’s customers are mature women. Express targets a young trend-driven customer, and Helly Hansen serves the sailing population. Jack Wills' fashion products draw on British heritage looks updated for contemporary college students.

Only a few stores on Upper Thames Street are unique to Newport. Jason and Company is a jewelry shop selling original designs and designer brands. Style Newport embraces Newport's long history of sailing and the many years hosting the America's Cup with original jewelry inspired by nautical signal flags (Figure 4). Their enamel jewelry is crafted in Rhode Island, which is known for its costume jewelry industry. 


\section{Bowen's Wharf, Bannister's Wharf, and America's Cup Avenue}

Bowen's Wharf and Bannister's Wharf are the heart of the tourist area where visitors encounter restored schooners, yachts, and sailboats. Restaurants, bars, and art galleries alternate with retail shops. Bannister's Wharf features the historic Clarke Cooke House, which was moved to its present location during redevelopment. Symbols of Newport's maritime activities permeate this district: a large anchor sits as a sculpture and a sailboat mast acts as a flagpole. Store names such as The Sail Loft, Custom Canvas, Scrimshanders, and Upper Deck underscore Newport's reputation as a sailing town.

Bowen's Wharf has eleven fashion stores including Alex and Ani (a Rhode Island jewelry company), the Narragansett, and Chace N'Lulu. The fashion shops on Bannister's Wharf include two that have other stores in Newport located less than a mile away, Royal Male and Michael Hayes. Brahmin Handbags, next to the Clarke Cooke House, is an outlet for fine leather handbags produced by a family-owned company headquartered in nearby Fairhaven, Massachusetts. The founders chose the name 'Brahmin' to appeal to an upper-class clientele such as the legendary Boston Brahmins of the nineteenth century (Brahmin 2013). The Preservation Society of Newport County's museum shop is prominently located at the junction of America's Cup Avenue and Bannister's Wharf (Figure 5).

The wharf area caters to the boating crowd who do not venture far from the harbor. The merchandise offered includes moderate to better brands with some designer goods. During summer months, a pop-up shop called Malee's sells inexpensive hats, headbands, sunglasses, sweatshirts and T-shirts. 


\section{Lower Thames Street}

Lower Thames begins at Memorial Boulevard where Upper Thames leaves off. The milelong street has a mix of older residential and commercial buildings, some with storefronts on the ground floor and apartments above. Many of the buildings are shingle style, a hallmark of New England seaside architecture. Old stone buildings survive; the Armory provides shared space for antique dealers, and Perry Mill houses retail shops.

Lower Thames Street features over thirty fashion shops selling jewelry and apparel including two vintage fashion stores. Some shops have 'island' names like Island Outfitters and Island Pursuit (Figure 6), or 'seashore' names like Newport Seafoam Trading Company and Chez Shell. Island Outfitters, a regional chain, offers moderately priced brands for men and women that sell well in New England including Lily Pulitzer, a brand popular with New Englanders, and Vineyard Vines, a 'preppy' clothing line based on the Martha's Vineyard lifestyle. Sequin is a New York based costume jewelry company with additional stores on Bellevue Avenue. Patagonia's shop is the only national chain.

Lower Thames Street, with its many small boutiques, experiences high turnover. Yet shops some have cultivated a loyal following among locals and Salve Regina University students. Pink Pineapple, Tropical Gangsters, and Cabbage Rose, all of which have long residencies on this street, feature young women's fashion. Other mainstays include Down Under Jewelry, whose discriminating owner buys only merchandise handcrafted by artisans for her store. 
The shops thin out towards the end of Thames Street. Specialty businesses include Thames Street Glass, where customers may participate in glass blowing, and Team I Newport, which caters to sailing enthusiasts.

\section{Franklin Street and Spring Street}

Franklin Street and Spring Street are located in Newport's Historic Hill district. Historic storefronts with paned-glass windows alternate with residences. The area is only a short walk away from the waterfront, yet retail shops are far less frequent than along the main thoroughfares.

Franklin between Thames and Spring has a reputation as an 'antiques' street. During the economic downturn, some antiques businesses closed. They were replaced by small fashion-oriented shops such as Green Envy Eco-Boutique, which offers fair trade and sustainable merchandise, and Toci, a store focusing on cashmere products. A vintage clothing shop is located in the basement of the Green Envy store. Andria Bird Bride, a small bridal shop featuring gowns that are handmade in the United States, moved to Bowen's Wharf from the corner of Franklin and Spring after a car accidentally damaged the building.

The artisan tradition continues on Spring Street, where J.H. Breakell \& Co. sells jewelry inspired by nautical themes. The few clothing companies on Spring Street include the second Royal Male store, whose signage includes the words 'Best of British Clothing' (Figure 7). Royal Male carries English heritage brands targeting an uppermiddle class consumer. 


\section{Bellevue Avenue}

Bellevue Avenue is home to exclusive jewelry stores, art galleries, and clothing boutiques. Mansions line the southern end of Bellevue Avenue, while the shopping district is located in and around historic commercial buildings. The shops serve a discriminating clientele who appreciate luxury watches (Grenon's of Newport), designer fashions (Michael Hayes), and designer denim (Laura Jean). Angela Moore, which has shops in other resort locations, is an eponymous brand selling resort fashion, jewelry, and home goods. The Charlotte Kellogg and J. McLaughlin shops stock classic styles that appeal to conservative New England taste. Alloy Gallery features contemporary jewelry by local artisans, who are mostly graduates of Providence's Rhode Island School of Design. Only one national chain is located in the Bellevue shopping district - Talbots - a moderately priced store offering conservative fashion targeted to women age 35 and up. The Newport store enjoys a prominent corner location in the historic Travers Block (Figure 8). Opposite Talbots on Williams Street is Rib \& Rhein, a luxury store offering men's and women's designer brands with highly personalized service.

Across Memorial Boulevard are additional architecturally important buildings. The fashion shops in this stretch of Bellevue Avenue are not contiguous. Boston-based designer Sara Campbell, who has shops in Massachusetts, Connecticut, Florida, and Illinois, targets upper middle class women with her timeless contemporary designs. Argentinian-born Marcela Calvet designs and sells luxury handbags at Calvet Paris 1937. Local designer Katie Brierley's shop, Isoude, is located on John Street just off Bellevue.

\section{Washington Square and Long Wharf}


Bellevue Avenue ends at Washington Square, which has a grassy tree-lined park facing the Old Colony House and the Courthouse on one end, and the Brick Market on the other. On either side are commercial buildings including retail shops. Washington Square has two designer stores, Karol Richardson and Kristina Richards Studio. Karol Richardson's store, with its ample display windows, features her label mixed with other women's wear designers (Figure 9). She has two additional stores on Cape Cod. Kristina Richards, a native Rhode Islander, mixes well-known labels with up-and-coming designers to convey a 'beach-chic vibe' in her light-filled, whitewashed store. Both Karol Richardson and Kristina Richards Studio enjoy a loyal clientele. Price points are in the bridge category.

Long Wharf occupies an area that was once filled with navy outfitters and sleazy bars. During redevelopment, it was reconfigured as a strip mall. Stores are located in two buildings that face each other across a brick and cement courtyard. The design of this mall is not unique, but the brick buildings with dormered windows and captain's walks evoke a unified 'colonial' appearance. The shops include the national chains White House | Black Market, J. Crew, Joseph A. Bank, and the Gap.

The Long Wharf district continues across America's Cup Avenue towards the harbor. Two shops—Re-Sails/Hooley and New England Harbour Club—share a large corner space. Re-Sails sells items made from old sails, whereas Hooley produces active sportswear. New England Harbour Club features a mix of recognizable brands including the British brands Topshop and Topman.

\section{Broadway}


Broadway begins at two local landmarks in historic Washington Square, the Old Colony House and the Courthouse. The street first developed in the eighteenth century, but most of the early buildings are gone and have been replaced by Victorian structures. Broadway is a mixture of commercial and government buildings. The police station and city hall are located on Broadway as well as trendy restaurants and cafes, convenience stores, and a pawn shop. The street is a gathering place for nearby low-income residents as well as young people who patronize the bars and restaurants. The Broadway district is frequented for food and drink rather than shopping.

Closet Revival is the only store selling clothing and accessories, aside from the minimal selection of T-shirts at two nearby smoking accessory shops (Holy Smokes! and Ethnic Concepts) and the Salvation Army. Closet Revival is a consignment and vintage clothing shop that has enjoyed a long tenure at its Broadway location (Figure 10).

\section{Newport Mall}

The Newport Mall is a community shopping center located near major transportation routes. Officially known as the RK Newport Towne Center, it is near the US Naval base and the Newport Grand casino. Accessibility to the center is limited to vehicles and public buses. Its location on a heavily trafficked thoroughfare on Newport's perimeter prohibits pedestrian traffic.

RK Newport Towne Center currently has three anchor stores that sell clothing: Wal-Mart, Old Navy, and TJ Maxx (Figure 11). The center has a few smaller chain stores including Rue 21, Famous Footwear, and Payless Shoes. Personal service retailers include Supercuts and Signature Nails. Although signage is uniform among the various 
tenants, it does not brand RK Newport Towne Center as a quaint Newport shopping venue. This shopping center caters to consumers who value price and convenient parking more than an aesthetic shopping experience. Tourists do not frequent the Newport Mall.

\section{DISCUSSION}

Newport is far from being a global fashion city, yet its location, historic architecture, and cultural heritage attracts the type of visitor who is interested in fashion. Visitors who come for entertainment and relaxation value shopping as a pleasurable leisure activity. Despite not being a production center, Newport displays attributes of a small fashion city because of its fashion retail sector and its unique flavor as a resort town.

\section{Newport and Fashion Production}

Components contributing to a city's image as a fashion production site, according to Gilbert (2006), include presence of creative designers, fashion production networks, affordable rents, cultural institutions that display fashion, promotional vehicles, and fashion research and training institutes. Newport has a limited capacity for fashion production.

While artisans flourished in Newport during the colonial period, today Newport has few local fashion designers. Regional production is scarce for apparel, but abundant for jewelry designers. Providence's long history as a manufacturing site for costume jewelry is evident in the many shops selling jewelry designed in the Ocean State. Rents are affordable further away from the harbor, which accounts for the scattered location of the local designer/artisan shops. 
Katie Brierley is Newport's best example of a local designer. A graduate of the Fashion Institute of Technology, she designs simple chic clothes for the modern woman. Her studio is based in nearby Jamestown, Rhode Island, and she utilizes Boston's small sewing shops to produce her collections. Her Isoude line, priced in the bridge category, is sold in New York, Boston, and other cities. She moved her Newport shop from Bellevue Avenue to a side street in 2015 .

Newport has no citywide promotion of fashion and no regularly scheduled fashion shows. This is in contrast to Providence, which has hosted Style Week NorthEast since 2010 featuring young designers from Rhode Island and nearby Massachusetts. Only wedding magazines and annual bridal shows promote Newport as a destination for fashionable weddings. Newport does have a fashion blogger, Andrea McHugh, who comments on fashion news related to the city. Her blog, Newport Stylephile, is 'a fashion and style blog that celebrates the Newport, Rhode Island lifestyle.' (McHugh 2015).

Three historical preservation organizations regularly mount small fashion exhibitions. The Historical Society displays colonial and early nineteenth-century dress while the Preservation Society features Gilded Age fashion. Doris Duke's home, Rough Point, hosts exhibitions drawn from her legendary designer wardrobe.

The state of Rhode Island is home to several research and training institutes that offer instruction in fashion design and merchandising, notably the Rhode Island School of Design (RISD) and the University of Rhode Island (URI). Students with aspirations to work in fashion after graduation are available for internships and part-time employment. A few entrepreneurs have started their own fashion businesses in Newport post graduation. 


\section{Newport as a Fashion City}

Newport clearly is a site for fashion consumption rather than fashion production. According to David Gilbert, characteristics that appeal to shoppers include a distinctive built environment, symbolically significant streets and districts for shopping, unique independent shops, and a fashion tradition with place-specific elements (Gilbert 2006). These characteristics are reflected in the unique features that Newport offers its visitors.

\section{A Distinctive Built Environment}

Newport's waterfront location in a historical setting draws visitors. One of the main attractions of shopping in Newport is its historical ambiance. The city's architectural heritage extends to its retail sector because many shops are located in restored buildings or old storefronts. Windows are often multi-paned, like the windows that characterized small shops in the eighteenth and early nineteenth centuries before the invention of plate glass. Even new buildings are constructed in historic New England architectural styles. Potted plants, window boxes, cobblestone streets, brick walkways, and historical street lights add to the shopping experience. The signage on many shops evokes earlier eras. Hand-carved wooden signs with gold leaf lettering and signboards projecting above doorways are popular in all shopping districts except the Newport Mall.

The numerous antique stores accentuate the historical feel. They range from small shops that are open on an intermittent basis to cooperatives such as the shared space in the old Armory building on Lower Thames Street. Antique shops often purvey 
merchandise that may be considered fashionable: estate jewelry, costume jewelry, and vintage clothes.

Newport's location, however, is both an advantage and disadvantage. Unlike other island communities in New England, Aquidneck Island is easily accessible by car. While the city draws many visitors in the summer, it slows down in the winter months. Reducing hours of operation and developing an online presence are common strategies for some small fashion-forward boutiques. Some shops in the tourist shopping districts along Thames Street close altogether during the winter months. On Bowen's and Bannister's wharves, however, shops must stay open year round as required by their leases.

\section{Significant Streets and Districts for Shopping}

Newport has several historical streets and districts for shopping. Upper Thames Street has enjoyed a reputation for shopping since colonial days. Bowen's and Bannister's wharves witnessed goods being sold directly from the ships docked there in the eighteenth and nineteenth centuries. Bellevue Avenue's reputation as an elite shopping district dates from the Gilded Age. These historic streets and districts regained their significance as shopping districts following redevelopment.

The geography of Newport's harbor and tourist attractions, however, fragments the shopping experience. The way in which the downtown area developed in the post urban renewal era spread out the shopping districts. Only the most dedicated shopper could find all the stores that might appeal to her (or him) because they are scattered throughout the city. Guidebooks include lists of 'where to shop,' but it is mostly by 
chance that someone finds a favorite store. While some carefully curated boutiques are in the high-traffic Bowen's/Bannister's Wharf area, others are on Bellevue Avenue or in Washington Square, removed from the main thoroughfare.

Kristen Williams (2010), in her dissertation on waterfronts in contemporary Rhode Island, presents Newport as a spectacle for tourism that attracts white, affluent, primarily middle and upper class tourists. She notes that middle-class tourists enjoy visiting historical sites as entertainment with shopping as part of that entertainment. Thus, it is not surprising that most stores in the downtown 'historic' shopping districts along Thames Street cater to this target market. While there are no luxury brands such as Louis Vuitton or Prada, many of the shops offer merchandise in the moderate to bridge price zones. These are the price points affordable by the American middle class. Further, the types of merchandise on offer appeals to this target market.

The apparel and jewelry stores with higher price points tend to be located on Bellevue Avenue, Bowen's Wharf, Bannister's Wharf, Spring Street, and Washington Square. Michael Hayes, for example, has two stores on Bellevue (one is Michael Hayes for Kids) and one on Bannister's Wharf.

\section{Unique Stores: National Chains versus Independent Boutiques}

Newport's retail sector has a mix of chain stores, both national and regional, and independent boutiques. Newport has no restrictions prohibiting chain stores, unlike some of its island neighbors in Massachusetts, notably Nantucket (Stowe 2006). Newport has welcomed national chain stores in tourist areas as well as the Newport Mall. Banana Republic, Chico's, and Express have prominent stores on Upper Thames Street. J. Crew, 
the Gap, and White House | Black Market have stores in Long Wharf Mall. Brooks Brothers is in the Brick Market Place. Talbots occupies a prime location on prestigious Bellevue Avenue. Besides Walmart, no big box stores have locations in Newport. Instead, they are in nearby Middletown on a main thoroughfare along with car dealerships, building supply stores, and supermarkets.

A few fashion brands are regional: Brahmin Handbags, Island Outfitters, and Sara Campbell. Some of the shops that offer resort wear have locations where the yachting crowd spends their winters such as Palm Beach, Florida and St. Barths in the Caribbean. Boutiques add character to a retail landscape as noted by Rantisi (2011: 202). Newport has many unique fashion shops. These fall into two categories: those that offer locally-made fashion apparel and jewelry, and those that sell carefully selected merchandise that appeals to Newport's visitors. These shops pull together fresh looks from small fashion labels and make the shopping experience unique. While few in number and spread out over seven of the nine shopping districts, independent boutiques boost Newport's reputation as a fashionable resort city. Visitors as well as locals shop stores such as Michael Hayes and Karol Richardson to build their wardrobes.

While locally designed apparel is rare, jewelry is another matter. All the shopping districts surveyed include shops selling jewelry. Goods are offered at all price ranges, from inexpensive throwaway baubles to handcrafted jewelry by local artisans. Artisan jewelers often graduated from the Rhode Island School of Design in Providence. Gallery nights — on the second Thursday of the month from February to December — call attention to these artists. 
Jewelry shops are a convenient solution to the problem of seasonality of fashion merchandise. Sizing is not the issue that it is in clothing and footwear. Although jewelry has a 'style' shelf life, its fashionability is not as short-lived as clothes or shoes. Last year's merchandise is still salable after a slow winter whereas clothes and shoes must be marked down to make way for the new season's styles.

Like many summer communities, Newport has a plethora of shops selling Tshirts, sweatshirts, and trinkets. These shops are concentrated in areas along the wharfs, America's Cup Avenue, and Thames Street. These are the shopping districts frequented by tourists walking near the harbor front. Spring Street, Bellevue Avenue, Broadway, and the Newport Mall do not have tourist T-shirt shops. Most of the T-shirts are unremarkable: words and/or images signal that the wearer has been to Newport (e.g., the word 'Newport' sometimes with the addition of a sailboat or a lobster). Unique to Newport is the Bite Me Live Bait Co., which has copyrighted its slogan. Its prominent location in the historic Perry Mill Market at the junction of America's Cup Avenue, Lower Thames Street, and Memorial Boulevard guarantees exposure for its original Tshirts.

Consignment, vintage, and second hand stores have increased in Newport as they have across the United States in recent years. These vary from designer resale shops located in high-end shopping districts (Wish off Bellevue Avenue) to low-income areas on Broadway (Closet Revival). Estate jewelry can be found in the Brick Market Place (House of Windsor) and on Bellevue Avenue (Three Golden Apples). Someone who wanted to shop Newport's vintage stores would need to visit numerous shopping districts, as these stores are spread out. 
Some stores have more than one shop in Newport, one near the harbor front and another on the shopping streets in well-to-do residential areas like Bellevue Avenue and the Historic Hill. These include apparel stores Michael Hayes, Royal Male, and jewelry shop Sequin. Sequin, which sells moderately priced costume jewelry, has three stores, two within a block of each other. In 2011, one of the Bellevue Avenue stores shared space with Badgley Mischka, designers of evening gowns, cocktail dresses, and caftans. The concept of a seasonal pop-up store is reminiscent of the London, Paris, and New York retailers who opened shops for the summer season in the same Bellevue Avenue location during the Gilded Age.

David Gilbert's point regarding shopping tourism in Paris at the end of the nineteenth century could easily apply to Newport. He notes that 'the fashion object that was being consumed was the city itself .... Those Americans who traveled to experience Paris were just part of a wider process of popular consumption of the idea of Paris as an elite space' (Gilbert 2011: 241). Visitors to Newport in the twenty-first century may feel the same way: it does not matter so much what one buys in Newport, as long as something is purchased to commemorate the experience. The national chain stores that offer mass fashion - such as the Gap, Express, and Banana Republic - count on this phenomenon, as do shops selling T-shirts and sweatshirts with a 'Newport' theme.

\section{Newport: A Fashion Tradition with Place-Specific Elements}

New England is known for its conservative fashion, and Newport does not stray far from this reputation. Conservative taste can be traced back to the region's Puritan roots. New England's restraint regarding fashion was evident in the nineteenth century when wealthy 
Boston women who ordered gowns from Paris couturiers reputedly left them in boxes for a year before wearing them; further, they 'scoffed at the outrageous styles worn on Broadway in New York City' (Welters 2004: 136). This conservatism strengthened in the 1950s with the emergence of the Ivy League style at the region's elite colleges: Harvard, Yale, Brown, and Dartmouth. The Ivy League look re-emerged as 'preppy' style in the 1980s, referencing preparatory schools where classics from Brooks Brothers and J. Press prevailed.

Newport shops, along with other New England retailers, stock merchandise that appeals to this conservative taste. Such retailers include Brooks Brothers, Joseph A. Bank, Talbots, and Island Outfitters (which carries Lilly Pulitzer and Vineyard Vines). Some merchants, such as Royal Male and Jack Wills University Outfitters, project a deliberate image of British heritage. Shops selling classic styles enjoy year round patronage from locals, many of whom claim British heritage. The New England taste for good quality classic styles is apparent in seven of the nine shopping districts; the exceptions are Broadway and the Newport Mall.

Other shops target the resort crowd that comes to Newport during the summer from outside of New England. Merchandise is themed to summer and features more fashion-forward styles. Some of these shops, such as Angela Moore, have locations in other resort areas.

The legendary wedding of John F. Kennedy and Jacqueline Bouvier allowed Newport to become a favorite destination for weddings. In 2012, the daughter of Domenico De Sole, chairman of Tom Ford International, was married in Newport in a Tom Ford original (Malle 2012). The Newport Wedding Magazine, a wedding portal on 
the Discover Newport website, and an annual Bridal Show - at the mansions Rosecliff and Oceancliff — help young women plan their dream wedding in Newport. Only one bridal shop, Andria Bird Bride, exists in Newport and its environs. Several shops offer tuxedo rentals, and many beauty salons specialize in handling bridal parties. Brides who can afford the rental of a mansion don gowns by top wedding gown designers such as Vera Wang as evidenced in publicity about Newport weddings.

Tennis is a sport favored by visitors to Newport's International Tennis Hall of Fame. Tennis gear is available in several shops on Bellevue Avenue, and construction is underway in 2015 for the addition of retail shops on Memorial Boulevard near the famed courts.

Newport's position as a world-class sailing capital creates a need for shops that sell gear to the international sailing and yachting community during the summer months and for the boat shows. Such stores include Helly Hansen and Team I Newport. The presence of so many spectacular vessels in the harbor during the summer season inspires non-sailors to buy nautical-themed merchandise. This type of merchandise can be found in stores in the shopping districts near the harbor such as Style Newport with its nautical flag pins, and Re-Sails with its bags made from repurposed sails. A store name such as Style Newport associates fashion (nautical style) with the specific city (Newport).

\section{Conclusion}

Newport is blessed with a great location on Narragansett Bay and a long history. Much of that history is still visible on its streets and along the harbor. Historic houses, Gilded Age mansions, and the wharf areas attract visitors. 
The historical ambiance of the city is echoed in its fashion retail sector: shops are located in restored buildings that retain historical features. This setting appeals to the white, affluent upper-middle class tourists who visit the city. Tourists frequent seven of the nine shopping districts, where high-end shops are intermingled with T-shirt and trinket stores. Newport's low-income residents avoid the historic downtown shopping areas, patronizing the shopping mall instead where prices are lower.

Of Gilbert's components that contribute to a fashion city's image, only shops and shopping, and vibrant consumption are apparent in Newport. The other components, creative designers and fashion production, have a limited presence. However, as Gilbert further observed, cities themselves, such as Newport, may contribute to status as a fashion city. Most important for Newport are its sites of consumption, historic architecture, distinctive streets and unique seaside environment (Gilbert 2006).

The city offers unique shops located in historic shopping districts for the fashionforward individual. Particularly relevant to the City by the Sea are the tradition and significance of various streets and districts and a fashion tradition with place-specific elements. Newport's reputation as a center of colonial commerce, the seat of Gilded Age splendor, and home to world-class sailing gives the city a cachet that is complemented by the fashion sold in its shops. With vibrant shopping awaiting the visitor who is simultaneously immersed in Newport's heritage, it is appropriate to consider adding 'fashion city' to its reputation. After all, as with nineteenth-century Paris, the 'objects' consumed by visitors evoke Newport itself.

\section{NOTE}


${ }^{1}$ This article is based on research conducted as part of a graduate course entitled 'Fashion Studies: History, Culture, Business' under the supervision of the lead author. Each researcher was assigned a shopping district to investigate.

\section{ACKNOWLEDGEMENTS}

Thanks to Raphe Sciola, Administrative Assistant, Offices of the Mayor and City Manager, Newport City Hall, and William H. Leys, Executive Director (retired) of the Newport Redevelopment Agency.

\section{REFERENCES}

Baker, Joe (2011), 'Then and Now: Leys Century Store', The Newport Daily News, Feb. 17, p. A3.

Brahmin (2013), ‘About Us', http://www.Brahmin.com. Accessed July 14, 2013.

Breward, Christopher (2006), 'Preface', in Christopher Breward and David Gilbert (eds), Fashion's World Cities, Oxford: Berg, pp. ix-x.

City of Newport (2013), Proposed Budget FY 2013-2104.

http://www.cityofnewport.com/home/showdocument?id=2157. Accessed January 3, 2015. 
Davis, Deborah (2009), Gilded: How Newport Became America's Richest Resort, Hoboken: John Wiley and Sons.

Demirovic, Dunja. and Pivac, Tatjana. (2013), 'Belgrade (Serbia) as an Alternative Site or City of Fashion Tourism,' European Researcher 65, 12-2: pp. 2882-91.

Elliott, Maude Howe (1944), This Was My Newport, Cambridge, Mass: The Mythology Company.

Flynn, Judy Zaccagnini and Foster, Irene M. (2009), Research Methods for the Fashion Industry, New York: Fairchild Books.

Gamble, Melissa (2011), 'The Evolution of the Chicago Fashion Initiative,' in Linda Welters and Abby Lillethun (eds), The Fashion Reader, 2nd ed, Oxford and New York: Berg, pp. 597-99.

Gilbert, David (2006), 'From Paris to Shanghai: The Changing Geographies of Fashion's World Cities', in Christopher Breward and David Gilbert (eds), Fashion's World Cities, Oxford: Berg, pp. 3-32.

Gilbert, David (2011), 'World Cities of Fashion,' in Linda Welters and Abby Lillethun (eds), The Fashion Reader, 2nd ed, Oxford and New York: Berg, pp. 237-42. 
IHS Consulting (2013), Rhode Island Tourism 2013.

http://www.discovernewport.org/industry-resources/research. Accessed February 28, 2015.

Jefferys, C.P.B. (1976), Newport 1639-1976: An Historical Sketch, Newport: Newport Historical Society.

Kaiser, Susan B. and David Michalski (2012), 'Streetstyle: An Interview with Susan B.

Kaiser,' Streetnotes 20: 134-145. http://www.escholarship.org/uc/item/3c60k4bj. Accessed February 28, 2015.

Leys, William H. (2012), 'The Redevelopment Agency of Newport, Rhode Island. A Brief History: 1949-1992', Newport, RI.

Malle, Chloe (2012), 'Love Is All Around: Rickie De Sole \& Derek Webster', Vogue, September, p. 570.

Martínez, Javier Gimeno (2007), 'Selling Avant-garde: How Antwerp Became a Fashion Capital (1990-2002)', Urban Studies 44, 12: pp. 2449-64.

McHugh, Andrea (2015), The Newport Stylephile. http://newportstylephile.com/ Accessed February 17, 2015. 
Newport Discovery Guide (2009-2012), 'Newport Rhode Island Shopping.' http://www.newport-discovery-guide.com/newport-rhode-island-shopping.html. Accessed January 3, 2015.

Newport Historical Society (2015), 'A Brief History of Newport.' http://www.newporthistory.org/about/brief-history-of-newport/. Accessed February 28, 2015.

Rantisi, Norma M. (2011), ‘The Prospects and Perils of Creating a Viable Fashion Identity,' Fashion Theory 15, 2: pp. 259-66.

Stensrud, Rockwell (2006), Newport, a Lively Experiment 1639-1969, Newport: Redwood Library and Athenaeum.

Stone, Elaine (2008), The Dynamics of Fashion $3^{\text {rd }}$ ed., New York: Fairchild Books.

Stowe, Stacey (2006), 'Nantucket Votes to Ban Chain Stores from Downtown,' The New York Times, April 12.

Vainshtein, Olga (2006), 'Mapping Moscow Fashion: Spaces and Spectacles of Consumption', in Christopher Breward and David Gilbert (eds), Fashion's World Cities, Oxford and New York: Berg, pp. 135-58. 
Weller, Sally (2011), 'Popularizing Fashion in Melbourne, Australia,' in Linda Welters and Abby Lillethun (eds), The Fashion Reader, 2nd ed., Oxford and New York: Berg, pp. $243-49$.

Welters, Linda (2004), 'Fashion', in Michael Sletcher (ed.), New England: The Greenwood Encyclopedia of American Regional Cultures, Westport: Greenwood Press, pp. 131-64.

Williams, Kristen A. (2010), 'Waterfronts for Work and Play: Mythscapes of Heritage and Identity in Contemporary Rhode Island,' Unpublished doctoral dissertation, University of Maryland.

Zukin, Sharon (2004), Point of Purchase: How Shopping Changed American Culture, New York and London: Routledge. 